\title{
Medical Drop
}

National Cancer Institute

\section{Source}

National Cancer Institute. Medical Drop. NCI Thesaurus. Code C69442.

A unit of volume equal to approximately 0.08333 milliliter ( $1 \mathrm{~mL}=12$ medical drops). 